\title{
Effect of ensiling time on apparent total tract starch digestibility in Southern Brazilian
}

\author{
dairy herds
}

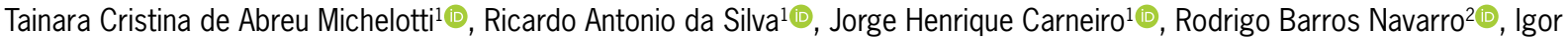 \\ Quirrenbach de Carvalho ${ }^{3}$, Eduardo Marostegan de Paula ${ }^{4}$, Luiz Felipe Ferraretto ${ }^{(0)}$, Mariana Caetano ${ }^{6}$, Dante Pazzanese Duarte \\ Lanna $^{7}$, Rodrigo de Almeida ${ }^{*}$ (1)
}

\begin{abstract}
'Universidade Federal do Paraná - Depto. de Zootecnia, R. dos Funcionários, 1540 - 80035-050 - Curitiba, PR - Brasil. ${ }^{2}$ Capal Cooperativa Agroindustrial, R. Saladino de Castro, 1375 - 84990-000 - Arapoti, PR - Brasil.

${ }^{3}$ G12Agro Pesquisa e Consultoria Agronômica, R. Coronel Luís Lustosa, 2296 - 85015-344 - Guarapuava, PR - Brasil. ${ }^{4}$ Instituto de Zootecnia/Centro APTA Bovinos de Corte, Rod. Carlos Tonani, km 94 - 14174-000 - Sertãozinho, SP Brasil.

Eniversity of Florida - Dept. of Animal Sciences, 2250

Shealy Dr. - 32611 - Gainesville, FL - USA.

${ }^{6}$ The University of Adelaide - Dept. of Animal and Veterinary Bioscience, 5371 - Roseworthy, SA - Australia.

־Universidade de São Paulo/ESALQ - Depto. de Zootecnia, Av. Pádua Dias, 11 - 13418-900 - Piracicaba, SP - Brasil.

*Corresponding author <ralmeida@ufpr.br>
\end{abstract}

Edited by: Antonio Faciola

Received April 05, 2019

Accepted August 20, 2019
ABSTRACT: Ensiling corn for longer periods is a strategy used to increase rumen bacteria access to starch. In fact, when corn is ensiled for insufficient periods, starch digestibility decreases, as evidenced by excreted starch. This study investigates the effects of corn silage ensiling time on starch digestibility of dairy cows through fecal starch analysis. The trial was conducted during the spring of 2013 and the fall of 2014 on twenty dairy herds located in the state of Paraná, southern Brazil. Total mixed ration (TMR), whole-plant corn silage (WPCS) and fecal samples were collected for determination of dry matter (DM), neutral detergent fiber (NDF), acid detergent fiber (ADF), lignin and starch. Apparent total tract starch digestibility (ATTSD) was calculated using equations developed by Fredin et al. (2014) and Bal et al. (1997). Data were analyzed using the CORR, REG and GLM procedures of SAS. Spring and fall WPCS were ensiled for 260 and 132 days, respectively $(p<0.01)$. There was no difference $(p>0.05)$ in ATTSD-Fredin from season to season though there was a trend $(p=0.11)$ towards greater ATTSD-Bal for spring samples. ATTSD-Bal was positively correlated with ensiling days $(r=0.31$ ). Starch digestibility was not negatively affected by WPCS harvesting maturity. Differences in post-ruminal starch digestion, variation between farms in DM intake and diets, limitations of the equations, influence of uncontrolled factors, and the small number of experimental units might have contributed to the absence of significant results. Overall, Bal et al. (1997) equation was more efficient in distinguishing ATTSD from different ensiling periods.

Keywords: ensiling period, fecal starch, whole-plant corn silage

\section{Introduction}

Corn is one of the main feedstuffs in dairy cow diets, present in both forage and concentrate portions. Corn stands out as an important energy source for the dairy industry and, according to Ferraretto (2017), wholeplant corn silage (WPCS) energy value contributed by starch is approximately $50 \%$. Considering the constant increase in feed costs, improving the utilization of dietary corn and its high starch concentration in dairy herds has become essential to maximize productivity.

Corn kernel fibrous pericarp and hydrophobic proteins, known as prolamins, protect the endosperm starch from rumen degradation. Therefore, breakage of the pericarp and degradation of starch encapsulating proteins could correspond to higher corn starch digestibility (Giuberti et al., 2014). With regard to Brazilian corn crops, their endosperm is known (Correa et al., 2002; Pereira et al., 2004) for its predominant vitreousness, a term used to classify the starch-protein matrices as being in an amorphous, glassy-like state (Giuberti et al., 2014). Ngonyamo-Majee et al. (2008) reported that vitreousness has a strong negative correlation with degradability measurements and, according to Hoffman et al. (2011), the ensiling process contributes to degradation of starch matrix proteins, which allows for greater access to starch by rumen bacteria. Considering that short periods of ensiling appear to be a common practice in Brazil, the longer ensiling time could be a useful strategy for dairy farmers to increase starch hydrolysis in the rumen (Kung Jr. et al., 2018).

Currently, fecal starch analysis is being used to estimate the amount of starch that escapes digestion. Zinn et al. (2007) reported that fecal starch alone explained 96 $\%$ of the variation in total tract starch digestion of feedlot cattle, and Fredin et al. (2014) found a close, linear relation between fecal starch concentration and total tract starch digestibility of lactating dairy cows $\left(\mathrm{R}^{2}=0.94\right)$. In this study, two equations (Bal et al., 1997; Fredin et al., 2014) were used to estimate ATTSD from fecal starch. The hypothesis is that this technique could evidence the losses in excreted starch observed in WPCS ensiled for insufficient periods. The objective of this study was to investigate the effects of WPCS ensiling time on starch digestibility of dairy cows through fecal starch analysis.

\section{Materials and Methods}

\section{Experiment locations and schedule}

The trial was conducted over two different periods: the 2013 spring season and the 2014 fall season. Twenty 
dairy herds associated with the Capal, Castrolanda and Frísia Cooperatives participated in this trial. Herds were located in the cities of Arapoti $\left(24^{\circ} 8^{\prime} \mathrm{S}, 49^{\circ} 49^{\prime} \mathrm{W}\right.$, altitude of $841 \mathrm{~m})$, Castro $\left(24^{\circ} 47^{\prime} \mathrm{S}, 50^{\circ} 0^{\prime} \mathrm{W}\right.$, altitude of $996 \mathrm{~m}$ ) and Carambeí (24 $56^{\prime} \mathrm{S}, 50^{\circ} 6^{\prime} \mathrm{W}$, altitude of $1038 \mathrm{~m})$, in the eastern center of the state of Paraná, southern Brazil, one of the most important regions for the Brazilian dairy industry.

Herds were chosen by convenience and were considered high yielding, with intensive (free-stall) or semi-intensive production systems, where Holstein cattle was the predominant breed and milking was carried out two or three times a day. In this region, such as is the case with many in this country, WPCS is ensiled annually at the beginning of the year, in the summer, during Jan or Feb. Therefore, shorter fermentation silages are usually used in the fall; while in spring longer fermentation silages integrate rations.

Typically, each herd was divided into two or more groups of lactating cows, according to milk yield (low, medium and high yields), calving order (primiparous and multiparous) and lactation stage (fresh cows, early, middle and later lactation). From each herd, only the highest producing group of cows was included in this study. Average daily milk yield was $41.8 \pm 5.9 \mathrm{~kg}$ and groups had on average $95.7 \pm 60.0$ cows, which corresponded to about $35 \%$ of the total of lactating cows.

All the experimental herds were on specific diets for lactating cows. Whole-plant corn silage was the main diet forage, corresponding to an average of $55.7 \pm 7.2 \mathrm{~kg}$ for each $100 \mathrm{~kg}$ of TMR, on an as-fed basis. The wholeplant corn silage daily provision varied between 25 and $35 \mathrm{~kg}$ per cow. Considering an average corn silage DM of 30 to $35 \%$, the ingredient represented approximately $40 \%$ of total DM intake.

\section{Collection of feed and fecal samples}

Samples of TMR and WPCS were collected from each farm in Nov of 2013 (spring) and Apr of 2014 (fall). Samples were kept under refrigeration at -20 degrees centigrade $\left({ }^{\circ} \mathrm{C}\right)$ until further analyses by an animal nutrition laboratory located in the city of Curitiba $\left(25^{\circ} 25^{\prime} \mathrm{S}, 49^{\circ} 16^{\prime} \mathrm{W}\right.$ and altitude $\left.934 \mathrm{~m}\right)$, in the state of Paraná, southern Brazil. Before the analyses, samples were dried at $65{ }^{\circ} \mathrm{C}$ for $72 \mathrm{~h}$ and then ground in a Wiley Miller stationary mill with a 1-millimeter $(\mathrm{mm})$ sieve.

Total mixed ration and WPCS were analyzed for $\mathrm{DM}$ at $105^{\circ} \mathrm{C}$ (for $24 \mathrm{~h}$ ), NDF, $\mathrm{NDF}$ and lignin, determined according to Van Soest et al. (1991). Starch content was analyzed using a modification of the method by Knudsen (1997). In addition to sample collection, WPCS and TMR mean particle sizes were determined using the Penn State Particle Separator (PSPS), following the technique specified by Kononoff et al. (2003).

Manure samples were collected following the same schedule as feed samples; two samples per herd, collected during the spring and the fall. Fecal samples were taken from undisturbed fresh pies in the cow lot, collected right after excretion and, by mixing 15 subsamples from different animals, a final $1 \mathrm{~kg}$ sample was prepared for each farm. Samples were immediately placed on ice for 1 to $4 \mathrm{~h}$ before freezing at $-20^{\circ} \mathrm{C}$. Samples were maintained at $-20{ }^{\circ} \mathrm{C}$ until further analyses. Fecal DM, NDF, ADF and lignin were analyzed by the same laboratory following the same methodology used for TMR and WPCS, while fecal starch was analyzed by an animal nutrition laboratory located in the city of Piracicaba $\left(22^{\circ} 43^{\prime} \mathrm{S}, 47^{\circ} 38^{\prime} \mathrm{W}\right.$, altitude of 547 $\mathrm{m})$, in the state of São Paulo, southeastern Brazil.

\section{Analyses of feed and fecal starch}

Starch content was determined in quadruplicate by an enzymatic colorimetric method. As described previously, WPCS, TMR and fecal samples were analyzed using a modification of the methodology proposed by Knudsen (1997). Briefly, for each reaction, a standard curve was setup using known concentrations of glucose, standard samples (starch and ground corn) and a blank. 0.40 and $0.20 \mathrm{~g}$ of fecal and feed samples, respectively, were weighed in 40 milliliters $(\mathrm{mL})$ tubes with screw caps. Thirty $\mathrm{mL}$ of sodium acetate buffer $\left(\mathrm{pH} 5.00 \pm 0.05,0.1 \mathrm{mols} \mathrm{L}^{-1}\right)$ and 50 microliters $(\mu \mathrm{L})$ of $\alpha$-amylase enzyme were added to the tubes. The tubes were then mixed in a vortex mixer and incubated for $1 \mathrm{~h}$ at $100{ }^{\circ} \mathrm{C}$. During incubation, the test tubes were mixed again at 10, 20 and $50 \mathrm{~min}$. Samples were then cooled down till they reached room temperature. Subsequently, $1 \mathrm{~mL}$ of $100 \mathrm{U} \mathrm{mL}^{-1}$ amyloglucosidase enzymes were added to test tubes, mixed and then incubated for $2 \mathrm{~h}$ at $60{ }^{\circ} \mathrm{C}$, and again mixed at $1 \mathrm{~h}$. After incubation, samples were once again cooled until reaching room temperature. The tubes were weighed for correction of volume, transferred to $50 \mathrm{~mL}$ centrifuge tubes, then centrifuged at 2.060 relative centrifugal force $(\mathrm{RCF})$ for $10 \mathrm{~min}$ at $10{ }^{\circ} \mathrm{C}$. From each centrifuge tube, $10 \mu \mathrm{L}$ of sample were used to react with $1 \mathrm{~mL}$ of a stable solution from a glucose commercial kit diluted in a ratio of 1:100. After $10 \mathrm{~min}$ of reaction at $23^{\circ} \mathrm{C}$, samples were read by spectrometry at 505 nanometers $(\mathrm{nm})$. In order to discount the quantity of free glucose from total glucose, an additional procedure was conducted following the same methodology, except for the addition of enzymes. Starch glucose, determined by the difference between total and free glucose, was converted to the equivalent starch polysaccharide values using a factor of 0.9 .

\section{Apparent total tract starch digestibility}

The two following equations were used to determine ATTSD (\%):

ATTSD-Fredin (Fredin et al., 2014) $=100-1.25 \times$ fecal starch;

ATTSD-Bal (Bal et al., 1997) $=[1-\| \%$ feed marker concentration / \% fecal marker concentration $) \times(\%$ fecal starch $/ \%$ feed starch $) /] \times 100$, considering lignin as the marker. 


\section{Statistical analysis}

Data were analyzed using the CORR and GLM procedures of SAS (Statistical Analysis System, v. 9.4). The statistical model included herd and season (spring and fall) as fixed effects. Each herd was considered as an experimental unit. In addition, continuous variables were tested for regression analysis using the REG procedure of SAS (Statistical Analysis System, v. 9.4). Statistical significance and trends were identified at $p \leq$ 0.05 and $p>0.05$ to $p \leq 0.15$, respectively.

\section{Results}

Whole-plant corn silage had an average of 260.5 and 132.0 ensiling days for both spring and fall samples, respectively $(p<0.001)$. Samples from the spring sampling period ranged from 97 to 309 days; meanwhile samples from the fall sampling period ranged from 53 to 438 days. Whole-plant corn silage in the fall showed more ensiling days variation between farms, especially three specific farms that had silos exceeding 400 days of ensiling.

Whole-plant corn silage and TMR chemical composition and mean particle size can be found by season in Tables 1 and 2, respectively. As regards WPCS (Table 1), there was no difference $(p>0.05)$ between sampling periods. Meanwhile, with regard to TMR (Table 2), fall samples had higher NDF $(p<0.001)$, $\operatorname{ADF}(p<0.05)$, and mean particle size $(p<0.05)$, but lower $(p=0.01)$ starch content compared to samples taken in the spring. These results corroborate with common dietary changes applied during the spring, a season with higher milk yields, when farmers increase TMR energetic values by adding more concentrate and reducing forage proportions.

Fecal composition and ATTSD are shown according to season in Table 3. Overall, there was no difference $(p>0.05)$ in fecal composition or ATTSD between the seasons studied, with the exception of fecal NDF, with greater $(p=0.03)$ fecal NDF values observed in the samples taken in the fall. In addition, there were trends of higher $(p=0.11)$ fecal DM and lower $(p=0.12)$ fecal lignin for the fall samples and higher $(p=0.11)$ ATTSDBal for the samples taken in the spring.
Apparent total tract starch digestibility frequency distribution according to the two different equations can be found in Figures 1 and 2. Spring sample ATTSDs were higher than $92 \%$ regardless of the equation used. In contrast, according to both equations, about $18 \%$ of the fall samples had starch digestibility values lower than $90 \%$, with a minimal value of $70 \%$.

Ensiling days were positively but poorly related to ATTSD-Bal $\left(\mathrm{R}^{2}=0.10 ; p<0.05\right.$; Figure 3$)$. Correlations between WPCS, TMR and fecal composition and ATTSD can be found in Table 4. In general, results

Table 1 - Adjusted means, respective standard errors and statistical significance for chemical composition and average particle size of whole-plant corn silage, according to seasons (spring, $n=20$; and fall, $n=20$ ).

\begin{tabular}{|c|c|c|c|c|}
\hline Variable & Spring & Fall & SEM $^{1}$ & $p$ value \\
\hline $\mathrm{CS}^{2} \mathrm{DM}\left(\%\right.$ of $\left.\mathrm{NM}^{3}\right)$ & 30.94 & 31.37 & 0.71 & 0.67 \\
\hline $\mathrm{CS}^{2} \mathrm{NDF}^{5}\left(\%\right.$ of $\left.\mathrm{DM}^{4}\right)$ & 41.72 & 43.00 & 0.76 & 0.25 \\
\hline $\mathrm{CS}^{2} \mathrm{ADF}^{6}\left(\%\right.$ of $\mathrm{DM}^{4}$ ) & 20.96 & 20.42 & 0.38 & 0.40 \\
\hline $\mathrm{CS}^{2}$ Lignin (\% of $\mathrm{DM}^{4}$ ) & 2.41 & 2.57 & 0.16 & 0.48 \\
\hline $\mathrm{CS}^{2}$ Starch $\left(\%\right.$ of $\left.\mathrm{DM}^{4}\right)$ & 30.08 & 30.81 & 0.56 & 0.37 \\
\hline $\mathrm{CS}^{2}$ Mean particle size $(\mathrm{mm})$ & 10.64 & 10.47 & 0.21 & 0.59 \\
\hline
\end{tabular}

${ }^{1} \mathrm{SEM}=$ standard error of the mean; ${ }^{2} \mathrm{CS}=$ corn silage; ${ }^{3} \mathrm{NM}=$ natural matter; ${ }^{4} \mathrm{DM}=$ dry matter; ${ }^{5} \mathrm{NDF}=$ neutral detergent fiber; ${ }^{6} \mathrm{ADF}=$ acid detergent fiber.

Table 2 - Adjusted means, respective standard errors and statistical significance for chemical composition and average particle size of total mixed ration, according to seasons (spring, $n=20$; and fall, $\mathrm{n}=20$ ).

\begin{tabular}{lrccc}
\hline Variable & Spring & Fall & SEM & $p$ value \\
\hline $\mathrm{TMR}^{2} \mathrm{DM}\left(\%\right.$ of $\left.\mathrm{NM}^{3}\right)$ & 45.10 & 45.65 & 0.60 & 0.52 \\
$\mathrm{TMR}^{2} \mathrm{NDF}^{5}\left(\%\right.$ of $\left.\mathrm{DM}^{4}\right)$ & 33.35 & 36.62 & 0.59 & $<0.001$ \\
$\mathrm{TMR}^{2} \mathrm{ADF}^{6}\left(\%\right.$ of $\left.\mathrm{DM}^{4}\right)$ & 16.05 & 17.39 & 0.45 & 0.05 \\
$\mathrm{TMR}^{2}$ Lignin $\left(\%\right.$ of $\left.\mathrm{DM}^{4}\right)$ & 1.84 & 2.00 & 0.13 & 0.37 \\
$\mathrm{TMR}^{2}$ Starch $\left(\%\right.$ of $\left.\mathrm{DM}^{4}\right)$ & 28.65 & 25.40 & 0.80 & 0.01 \\
$\mathrm{TMR}^{2}$ Mean particle size $(\mathrm{mm})$ & 7.34 & 8.26 & 0.29 & 0.04 \\
\hline${ }^{1} \mathrm{SEM}=$ standard error of the mean; ${ }^{2} \mathrm{TMR}=$ total mixed ration; & ${ }^{3 \mathrm{NM}}=$ natural \\
matter; ${ }^{4} \mathrm{DM}=$ dry matter; ${ }^{5 \mathrm{NDF}}=$ neutral detergent fiber; ${ }^{6} \mathrm{ADF}=$ acid \\
detergent fiber.
\end{tabular}

Table 3 - Adjusted means, minimum and maximum, respective standard errors and statistical significance of fecal composition and apparent total tract starch digestibility, according to seasons (spring, $n=20$; and fall, $n=20$ ).

\begin{tabular}{|c|c|c|c|c|c|c|c|c|}
\hline \multirow{2}{*}{ Variable } & \multicolumn{3}{|c|}{ Spring } & \multicolumn{3}{|c|}{ Fall } & \multirow{2}{*}{ SEM $^{1}$} & \multirow{2}{*}{$p$ value } \\
\hline & Mean & Min. & Max. & Mean & Min. & Max. & & \\
\hline Fecal $\mathrm{DM}^{2}\left(\%\right.$ of $\mathrm{NM}^{3}$ ) & 13.16 & 10.59 & 15.36 & 14.03 & 11.01 & 19.24 & 0.36 & 0.11 \\
\hline Fecal $\mathrm{NDF}^{4}\left(\%\right.$ of $\mathrm{DM}^{2}$ ) & 48.81 & 38.33 & 57.39 & 51.64 & 43.53 & 68.22 & 0.84 & 0.03 \\
\hline Fecal $\mathrm{ADF}^{5}\left(\%\right.$ of $\left.\mathrm{DM}^{2}\right)$ & 26.45 & 19.85 & 33.97 & 26.95 & 21.77 & 41.35 & 0.70 & 0.63 \\
\hline Fecal Lignin (\% of DM²) & 7.31 & 5.04 & 12.60 & 6.40 & 3.73 & 13.93 & 0.39 & 0.12 \\
\hline Fecal Starch (\% of DM²) & 3.40 & 1.46 & 5.67 & 3.93 & 1.66 & 11.10 & 0.37 & 0.33 \\
\hline ATTSD 6 -Fredin & 95.91 & 92.85 & 98.14 & 95.04 & 86.04 & 97.89 & 0.47 & 0.33 \\
\hline ATTSD $^{6}$-Bal & 96.80 & 93.63 & 98.60 & 94.06 & 70.08 & 98.29 & 1.15 & 0.11 \\
\hline
\end{tabular}

${ }^{1} \mathrm{SEM}=$ standard error of the mean; ${ }^{2 \mathrm{DM}}=$ dry matter; ${ }^{3} \mathrm{NM}=$ natural matter; ${ }^{4} \mathrm{NDF}=$ neutral detergent fiber; ${ }^{5} \mathrm{ADF}=$ acid detergent fiber; ${ }^{6} \mathrm{ATTSD}=$ apparent total tract starch digestibility. 
Table 4 - Correlations between corn silage, total mixed ration, fecal composition and apparent total tract starch digestibility.

\begin{tabular}{|c|c|c|c|c|c|c|c|c|c|c|c|c|c|c|c|}
\hline & $\begin{array}{c}\text { Ensiling } \\
\text { days }\end{array}$ & $\begin{array}{l}\text { CS } \\
\text { DM }\end{array}$ & $\begin{array}{c}\text { CS } \\
\text { NDF }\end{array}$ & $\begin{array}{c}\text { CS } \\
\text { Lignin }\end{array}$ & $\begin{array}{c}\text { CS } \\
\text { Starch }\end{array}$ & $\begin{array}{l}\text { TMR } \\
\text { DM }\end{array}$ & $\begin{array}{l}\text { TMR } \\
\text { NDF }\end{array}$ & $\begin{array}{c}\text { TMR } \\
\text { Lignin }\end{array}$ & $\begin{array}{l}\text { TMR } \\
\text { Starch }\end{array}$ & $\begin{array}{c}\text { Fecal } \\
\text { DM }\end{array}$ & $\begin{array}{l}\text { Fecal } \\
\text { NDF }\end{array}$ & $\begin{array}{l}\text { Fecal } \\
\text { Lignin }\end{array}$ & $\begin{array}{l}\text { Fecal } \\
\text { Starch }\end{array}$ & $\begin{array}{l}\text { ATTSD- } \\
\text { Fredin }\end{array}$ & $\begin{array}{c}\text { ATTSD- } \\
\text { Bal }\end{array}$ \\
\hline Ensiling days & & -0.14 & 0.07 & 0.17 & 0.08 & -0.12 & $-0.33^{*}$ & -0.13 & 0.15 & -0.02 & 0.02 & $0.37^{*}$ & 0.25 & 0.25 & $0.31^{*}$ \\
\hline CS DM & & & $-0.51^{* *}$ & * * -0.23 & 0.26 & $0.38^{*}$ & -0.12 & 0.09 & -0.03 & 0.05 & -0.10 & 0.07 & 0.24 & -0.24 & -0.28 \\
\hline CS NDF & & & & $0.47^{* *}$ & $-0.42^{* *}$ & $-0.43^{* *}$ & 0.16 & 0.08 & 0.02 & 0.10 & 0.23 & -0.17 & 0.07 & -0.07 & -0.08 \\
\hline CS Lignin & & & & & -0.24 & -0.09 & 0.17 & 0.11 & $-0.33^{*}$ & 0.23 & 0.09 & 0.14 & -0.19 & 0.19 & 0.11 \\
\hline CS Starch & & & & & & 0.17 & -0.07 & -0.09 & 0.00 & 0.09 & 0.08 & 0.06 & -0.16 & 0.16 & 0.08 \\
\hline TMR DM & & & & & & & -0.23 & -0.15 & -0.26 & 0.13 & -0.30 & -0.10 & 0.13 & -0.13 & -0.11 \\
\hline TMR NDF & & & & & & & & $0.54^{* *}$ & ${ }^{*}-0.50^{* * *}$ & 0.15 & 0.30 & -0.06 & -0.05 & 0.05 & -0.21 \\
\hline TMR Lignin & & & & & & & & & $-0.36^{\star}$ & $0.32^{*}$ & $0.38^{*}$ & 0.12 & 0.06 & -0.06 & . \\
\hline TMR Starch & & & & & & & & & & -0.22 & -0.03 & 0.11 & -0.05 & 0.05 & . \\
\hline Fecal DM & & & & & & & & & & & 0.16 & -0.26 & 0.03 & -0.03 & -0.25 \\
\hline Fecal NDF & & & & & & & & & & & & 0.20 & $-0.51^{* * *}$ & $0.51^{* * *}$ & * 0.21 \\
\hline Fecal Lignin & & & & & & & & & & & & & -0.24 & 0.24 & . \\
\hline Fecal Starch & & & & & & & & & & & & & & & . \\
\hline ATTSD-Fredin & & & & & & & & & & & & & & & $0.83^{* * *}$ \\
\hline ATTSD-Bal & & & & & & & & & & & & & & & \\
\hline
\end{tabular}

${ }^{*} p \leq 0.05 ;{ }^{* *} p \leq 0.01 ;{ }^{* *}{ }^{*} p \leq 0.001 ;$ "." correlations omitted for confounding effects. $C S=$ corn silage; TMR = total mixed ration; DM = dry matter; NDF = neutral detergent fiber; ATTSD = apparent total tract starch digestibility.

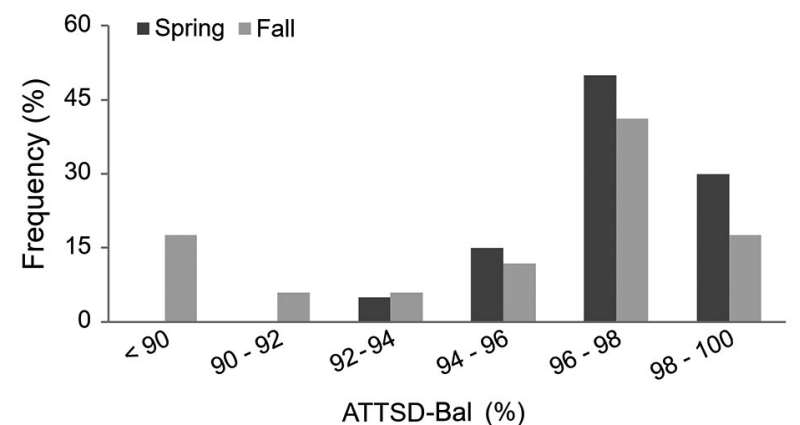

Figure 1 - Frequency distribution of apparent total tract starch digestibility (ATTSD-Bal) for spring and fall samples, calculated according to Bal et al. (1997).

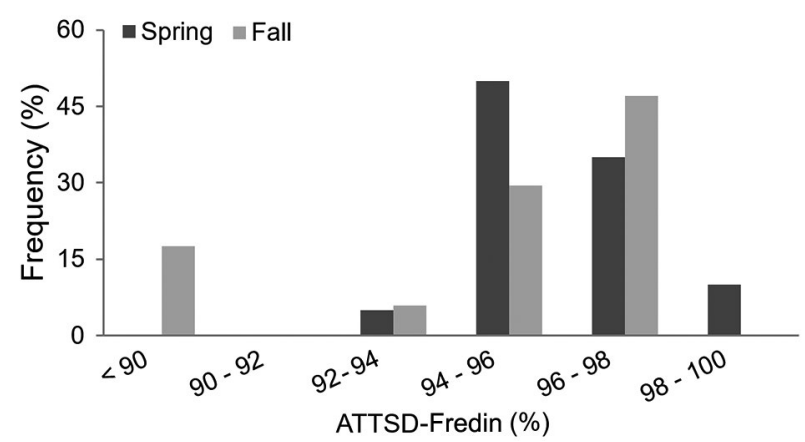

Figure 2 - Frequency distribution of apparent total tract starch digestibility (ATTSD-Fredin) for spring and fall samples, calculated according to Fredin et al. (2014).

showed very weak to moderate correlations. It is possible to highlight the positive correlation between ensiling days and ATTSD-Bal $(r=0.31 ; p<0.05)$ and the strong positive correlation between the two ATTSD equations $(\mathrm{r}=0.83 ; p<0.001)$.

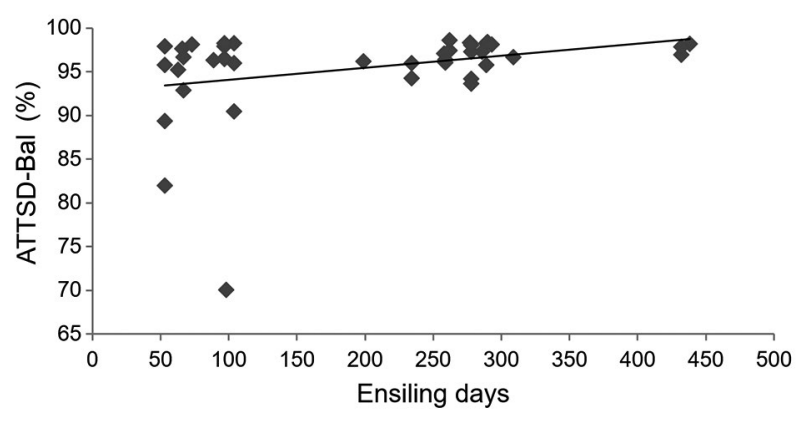

Figure 3 - Effect of ensiling days on apparent total tract starch digestibility (ATTSD-Bal), calculated according to Bal et al. (1997). Prediction of ATTSD-Bal (\%) can be calculated from the following equation: $y=(0.014 \pm 0.007) \times$ ensiling days $+(92.73 \pm 1.54)$; root mean square error $(\mathrm{RMSE})=4.93, \mathrm{R}^{2}=0.10 ; p<0.05$, $n=40$.

\section{Discussion}

In dairy cows, total tract starch digestibility can range from 70 to $100 \%$ (Ferraretto et al., 2013; Firkins et al., 2001) and is influenced by numerous factors (Fredin et al., 2014), including ensiling time, harvesting maturity, hybrid and endosperm type, grain processing or their many interactions (Ferraretto et al., 2013; Hoffman et al., 2011). A positive effect of WPCS prolonged storage on ruminal in vitro starch digestibility has been reported in recent studies (Der Bedrosian et al., 2012; Ferraretto et al., 2016, 2015a, 2015b; Windle et al., 2014). The general hypothesis is that extended ensiling time increases starch digestibility through the degradation of the hydrophobic prolamin protein matrix that surrounds starch (Hoffman et al., 2011; Windle et al., 2014) and represents a physicochemical barrier to amylolytic rumen microorganisms (McAllister et al., 1994). 
Numerous regression equations predicting starch digestibility from fecal starch have been published over recent years, showing a close relationship between these two variables. Therefore, we hypothesized that the effects of ensiling time on starch digestibility could be predicted through fecal starch analysis. Overall, results showed positive but weak correlation $(\mathrm{r}<0.31)$ between ATTSD and ensiling days. In addition, ATTSD was poorly predicted by ensiling days $\left(\mathrm{R}^{2} \leq 0.10\right)$ and there was no difference $(p=0.33)$ in ATTSD-Fredin between sampling seasons. Nevertheless, there was a trend to higher $(p=0.11)$ ATTSD-Bal for longer period ensiling samples (spring) compared to shorter period ensiling samples (fall). We believe that the Bal et al. (1997) equation was more efficient in distinguishing ATTSD between sampling seasons because, different from the Fredin et al. (2014) equation, it takes into account both lignin and starch fecal and feed concentrations.

Huibregtse et al. (2012), in a similar trial, found similar results for fecal starch and calculated ATTSD for fall and spring WPCS samples. For this experiment, the authors used an equation by Ferraretto and Shaver (2012), which was a preliminary version of the Fredin et al. (2014) equation, where ATTSD $=(100 * \mid 0.9997$ - $0.0125 *$ fecal starch). The authors also found approximately seven percentage units greater in vitro starch digestibility for spring WPCS when compared to fall samples. However, they emphasize that this difference between sampling periods was not sufficient to be detected through the fecal starch technique. Huibregtse et al. (2012) indicated that differences in post-ruminal starch digestion, dry matter intake and ration composition are possible explanations for the absence of a difference in fecal starch when comparing the two sampling periods.

Moreover, Owens et al. (2016), when evaluating published regression equations, concluded that the relationship of starch digestibility and fecal starch must be curvilinear, not linear. According to the authors, although these two variables are mathematically linked, additional factors are essential for an accurate relationship: (a) daily fecal output, which varies with the indigestibility of dietary DM; and (b) starch intake, which varies with its dietary concentration and dry matter intake.

Considering the influence of WPCS harvesting maturity and moisture content in starch digestibility, Windle et al. (2014) found lower in vitro ruminal starch digestibility of late-harvested corn (40\% DM) when compared to early-harvested corn (31\% DM). In addition, Ferraretto and Shaver (2012) observed lower total tract starch digestibility when lactating cows were fed with corn silage harvested with advanced maturity (DM higher than $40 \%$ ). Despite the sizeable difference of whole-plant corn silage DM among herds, with values ranging from 22 to $39 \%$ and a coefficient of variation of $11 \%$, our results showed no difference ( $p=0.67)$ between sampling periods. All analyzed WPCS samples showed DM values lower than $40 \%$, with a maximum of $37 \%$ for spring samples and a maximum of $39 \%$ for fall samples. Therefore, although WPCS lower moisture content at harvest could have a negative impact on the starch digestibility of dairy cows, our results suggest this was not the case for the studied herds.

When evaluating WPCS starch digestibility, Ferraretto (2017) emphasizes the importance of not only ensiling time, but also the potential interactions between hybrid, harvest maturity, kernel processing and ensiling time. For example, a study by Ferraretto et al. (2015a) evaluating the interaction between hybrid types and ensiling time on WPCS starch digestibility reported that extended ensiling time did not attenuate the negative effects of kernel vitreousness or maturity at harvest on starch digestibility. In the present study, data regarding corn hybrid type, endosperm vitreousness and kernel processing were not measured and the effect of ensiling time alone was not sufficient to evidence differences in ATTSD between sampling periods.

\section{Conclusions}

In conclusion, although in the present study fecal starch analysis was not able to detect differences in starch digestibility according to sampling period, numerous studies support the recommendation that prolonging WPCS ensiling time could be a positive practice in order to increase dietary starch digestibility in dairy cows. Differences in post-ruminal starch digestion, DM intake and rations; limitations of the equations; influence of uncontrolled factors; and the small number of experimental units might have contributed to the absence of significant results.

Overall, Bal et al. (1997) equation was more efficient in distinguishing ATTSD from different ensiling periods. Regardless of our results, we believe that a periodic determination of fecal starch, especially together with feed composition and DMI, could provide important information regarding dietary starch digestibility and could be used as a method to evaluate feed processing efficiencies.

\section{Authors' Contributions}

Conceptualization: Almeida, R.; Lanna, D.P.D.; Ferraretto, L.F. Data acquisition: Silva, R.A.; Carneiro, J.H.; Navarro, R.B.; Carvalho, I.Q. Data analysis: Almeida, R.; Caetano, M.; Paula, E.M.; Michelotti, T.C.A. Writing and editing: Michelotti, T.C.A.; Paula, E.M.; Almeida, R.; Ferraretto, L.F.; Lanna, D.P.D.

\section{References}

Bal, M.A.; Coors, J.G.; Shaver, R.D. 1997. Impact of the maturity of corn for use as silage in the diets of dairy cows on intake, digestion, and milk production. Journal of Dairy Science 80: 2497-2503. 
Correa, C.E.S.; Shaver, R.D.; Pereira, M.N.; Lauer, J.G.; Kohn, K. 2002. Relationship between corn vitreousness and ruminal in situ starch degradability. Journal of Dairy Science 85: 30083012.

Der Bedrosian, M.C.; Nestor Jr., K.E.; Kung Jr., L. 2012. The effects of hybrid, maturity, and length of storage on the composition and nutritive value of corn silage. Journal of Dairy Science 95: 5115-5126.

Ferraretto, L.F. 2017. Impact of starch content and digestibility in dairy cattle diets. University of Florida, Department of Animal Science, Gainesville, FL, USA. Available at: http://dairy.ifas.ufl. edu/rns/2017/Ferraretto.pdf [Accessed 19 Nov, 2018]

Ferraretto, L.F.; Crump, P.M.; Shaver, R.D. 2015a. Effect of ensiling time and exogenous protease addition to whole-plant corn silage of various hybrids, maturities, and chop lengths on nitrogen fractions and ruminal in vitro starch digestibility. Journal of Dairy Science 98: 8869-8881.

Ferraretto, L.F.; Crump, P.M.; Shaver, R.D. 2013. Effect of cereal grain type and corn grain harvesting and processing methods on intake, digestion, and milk production by dairy cows through a meta-analysis. Journal of Dairy Science 96: 533-550.

Ferraretto, L.F.; Fredin, S.M.; Muck, R.E.; Shaver, R.D. 2016. Case Study: Microbial inoculant and ensiling time effects on fermentation profile, nitrogen fractions, and ruminal in vitro and in situ starch digestibility in corn shredlage and latematurity corn silage. The Professional Animal Scientist 32: 861-868.

Ferraretto, L.F.; Shaver, R.D. 2012. Meta-analysis: effect of corn silage harvest practices on intake, digestion, and milk production by dairy cows. The Professional Animal Scientist 28: 141-149.

Ferraretto, L.F.; Shaver, R.D.; Massie, S.; Singo, R.; Taysom, D.M. 2015b. Effect of ensiling time and hybrid type on fermentation profile, nitrogen fractions, and ruminal in vitro starch and neutral detergent fiber digestibility in whole-plant corn silage. The Professional Animal Scientist 31: 146-152.

Firkins, J.L.; Eastridge, M.L.; St-Pierre, N.R.; Noftsger, S.M. 2001. Effects of grain variability and processing on starch utilization by lactating dairy cattle. Journal of Animal Science 79: 218238.

Fredin, S.M.; Ferraretto, L.F.; Akins, M.S.; Hoffman, P.C.; Shaver, R.D. 2014. Fecal starch as an indicator of total-tract starch digestibility by lactating dairy cows. Journal of Dairy Science 97: 1862-1871.

Giuberti, G.; Gallo, A.; Masoero, F.; Ferraretto, L.F.; Hoffman, P.C.; Shaver, R.D. 2014. Factors affecting starch utilization in large animal food production system: a review. Starch/Starke 66: 72-90.

Hoffman, P.C.; Esser, N.M.; Shaver, R.D.; Coblentz, W.K.; Scott, M.P.; Bodnar, A.L.; Schmidt, R.J.; Charley, R.C. 2011. Influence of ensiling time and inoculation on alteration of the starch-protein matrix in high-moisture corn. Journal of Dairy Science 94: 2465-2474.
Huibregtse, A.; Heuer, C.; Shaver, R.; Hoffman, P. 2012. Opportunities to improve starch digestibility on dairy farms. University of Wisconsin, Madison, WI, USA. Available at: https://fyi.extension.wisc.edu/forage/files/2014/01/ ImproveStarchDigestibility.pdf [Accessed Dec 29, 2018]

Kononoff, P.J.; Heinrichs, A.J.; Buckmaster, D.R. 2003. Modification of the Penn State forage and total mixed ration particle separator and the effects of moisture content on its measurements. Journal of Dairy Science 86: 1858-1863.

Knudsen, K.E.B. 1997. Carbohydrate and lignin contents of plant materials used in animal feeding. Animal Feed Science Technology 67: 319-338.

Kung Jr., L.; Shaver, R.D.; Grant, R.J.; Schmidt, R.J. 2018. Silage review: interpretation of chemical, microbial, and organoleptic components of silages. Journal of Dairy Science 101: 40204033.

McAllister, T.A.; Bae, H.D.; Jones, G.A.; Cheng, K.J. 1994. Microbial attachment and feed digestion in the rumen. Journal of Animal Science 72: 3004-3018.

Ngonyamo-Majee, D.; Shaver, R.D.; Coors, J.G.; Sapienza, D.; Lauer, J.G. 2008. Relationships between kernel vitreousness and dry matter degradability for diverse corn germplasm. II. Ruminal and post-ruminal degradabilities. Animal Feed Science Technology 142: 259-274.

Owens, C.E.; Zinn, R.A.; Hassen, A.; Owens, F.N. 2016. Mathematical linkage of total-tract digestion of starch and neutral detergent fiber to their fecal concentrations and the effect of site of starch digestion on extent of digestion and energetic efficiency of cattle. The Professional Animal Scientist 32: 531-549.

Pereira, M.N.; Von Pinho, R.G.; Bruno, R.G.S.; Calestine, G.A. 2004. Ruminal degradability of hard or soft texture corn grain at three maturity stages. Scientia Agricola 61: 358-363.

Van Soest, P.J.; Robertson, J.B.; Lewis, B.A. 1991. Methods for dietary fiber, neutral detergent fiber, and nonstarch polysaccharides in relation to animal nutrition. Journal of Dairy Science 74: 3583-3597.

Windle, M.C.; Walker, N.; Kung Jr, L. 2014. Effects of an exogenous protease on the fermentation and nutritive value of corn silage harvested at different dry matter contents and ensiled for various lengths of time. Journal of Dairy Science 97: 3053-3060.

Zinn, R.A.; Barreras, A.; Corona, L.; Owens, F.N.; Ware, R.A. 2007. Starch digestion by feedlot cattle: predictions from analysis of feed and fecal starch and nitrogen. Journal of Animal Science 85: 1727-1730. 